\title{
PENGARUH PENGERINGAN CONTOH TANAH TERHADAP BEBERAPA SIFAT FISIK DAN KIMIA TANAH BERSIFAT VERTIK SERTA KLASIFIKASINYA MENURUT TAKSONOMI TANAH
}

\author{
The Effect of Soil Samples Drying on Some Physical and Chemical Properties of Vertic Soils \\ and Their Classification according to Soil Taxonomy
}

\section{Djunaedi A. Rachim dan Dyah Tjahjandari}

Laboratorium Genesis, Klasifikasi dan Mineralogi Tanah, Jurusan Tanah, Fakultas Pertanian, Institut Pertanian Bogor Jalan Raya Pajajaran 1, Bogor 16144

\begin{abstract}
This laboratory experiment was carried out to study the effect of soil samples drying on physical and chemical properties of vertic soils and their classification according to soil taxonomy. Usually, soil analysis is held on samples in air-dried condition. Clays of some soil types, however, have irreversible properties upon drying which can cause a bias in the measurement results and classification outputs of the soils. To study the irreversibility of clays upon drying, 25 samples of vertic soils were treated in moist and air-dried conditions prior to analysis. Statistical procedure of Match Pair Comparison was used to test the treatments effect. The results showed that the irreversibility of clay upon drying was reflected in the measured soil properties except for exchangeable-Al and $-K$, organic-C, and soil-CEC. Nevertheless, the intensity of the clay irreversibility of the vertic soils studied was low. Therefore, the drying treatment did not affect their classification outputs.
\end{abstract}

Keywords: clay, irreversibility, soil taxonomy, vertic soils.

\section{PENDAHULUAN}

Data analisis laboratorium yang digunakan pada kebanyakan aktivitas pengelolaan tanah termasuk klasifikasi, khususnya sistem Taksonomi Tanah, biasanya diperoleh dari contoh tanah yang telah dikering-udarakan. Padahal, pengeringan dapat mengakibatkan bias pengukuran pada kebanyakan sifat Andisol dan kekelinuan klasifikasi pada tanah merah (Rachim, 1989; Rachim dan Darmawan, 1991). Hal tersebut disebabkan oleh sifat takdapat-balik (irreversible) liat terhadap pengeringan. Bila tanah vertik juga mempunyai sifat tersebut secara nyata, maka kekeliruan serupa dapat terjadi. Untuk meningkatkan kualitas data analisis bagi berbagai keperluan, maka sifat irreversible liat terhadap pegeringan pada berbagai jenis tanah perlu dipelajari.

Tujuan penelitian ini adalah untuk mempelajari perubahan sifat tanah bila contoh tanah yang dianalisis dikering-udarakan, pengaruhnya terhadap hasil klasifikasi menurut Taksonomi Tanah dan memilih kelembaban contoh tanah yang lebih baik untuk analisis laboratorium pada tanah-tanah bersifat vertik.

Dari percobaan sebelumnya (Rachim, 1989; Rachim dan Darmawan, 1991) sifat irreversible liat terjadi juga pada Podsolik Merah Kuning dan Latosol (Ultisol), walaupun intensitasnya lebih rendah daripada pada Andisol. Namun demikian, sifat tersebut telah menyebabkan kekelinuan klasifikasi. Dari 6 pedon yang diteliti, $50 \%$ hasil klasifikasinya menunjukkan kekeliruan. Pada Andisol, walaupun pengeringan tidak menyebabkan kekelinuan klasifikasi, tetapi perubahan cukup nyata terjadi pada kebanyakan sifat tanah sehingga dapat mengurangi ketepatan pendugaan sifat yang sebenamya di lapang. Hal demikian telah pula dilaporkan oleh Martini dan Palecia (1975) serta Uehara dan Gilman (1981).

Rachim, D.A. dan D. Tjahjandari. 1999. Pengaruh pengeringan contoh tanah terhadap beberapa sifat fisik dan kimia tanah bersifat vertik serta klasifikasinya menurut Taksonomi Tanah. J. II. Tan. Lirigk. 2(1):17-24. 
Pengaruh pengeringan pada tanah-tanah lain telah dilaporkan pula oleh. Hayness dan Swift (1985). Mereka menggunakan tanah Entisol dan Inceptisol. Pengeringan meningkatkan kadar $\mathrm{Al}$ dan $\mathrm{Fe}$ terekstrak EDTA, dan cenderung menurunkan $\mathrm{pH}$ tanah. Penelitian sebelumnya menggunakan tanah Spodosol (Bartlett dan James, 1980) juga menunjukkan hasil yang sama terhadap $\mathrm{Al}$ dan $\mathrm{Fe}$, namun untuk pH tidak menunjukkan hasil yang konsisten.

Hayness dan Swift (1985) melaporkan bahwa pengeringan pada tiga macam Inceptisol yang berbeda meningkatkan $\mathrm{Cu}, \mathrm{Zn}, \mathrm{Fe}$, dan $\mathrm{Mn}$ terekstrak EDTA, DTPA serta $\mathrm{HCl}$ dibandingkan penggunaan contoh lembab lapang. Walworth (1992) meneliti pengaruh pengeringan dan pembasahan kembali contoh tanah terhadap komposisi kimia larutan tanah dari tiga jenis tanah Typic Rhododult seri Colts Neck pasir berlempung. Typic Hapludult seri Collington lempung berpasir, dan Typic Hapludult seri Freehold lempung berpasir. Hasilnya menunjukkan bahwa perlakuan tersebut umumnya berpenganuh nyata terhadap komposisi larutan tanah dibandingkan dengan contoh tanah segar. Dari berbagai penelitian trersebut, pengeringan dapat mempengaruhi sifat-sifat tanah melalui sifat irreversible liat dan reaksi kimia khusus pada permukaan liat (Rachim dan Darmawan, 1991; Leubs, Stanford dan Scott 1956).

\section{METODE PENELITIAN}

Tanah yang diteliti adalah Aluvial dari Karawang, Sukamandi, Pamanukan, Losarang dan Cirebon, Jawa Barat dengan ciri utama adanya rekahan yang nyata pada lapisan permukaan (sifat vertik) pada musim kemarau. Pada setiap lokasi dibuat satu profil dan contoh tanah diambil dari setiap horison, masing- masing sebanyak 5 horison setiap profil, sehingga jumlah contoh dasar yang digunakan 25 buah. Pemilihan lokasi dan pengambilan contoh didasarkan pada metode Soil Survey Staff (1951).

Perlakuan yang dicobakan adalah lembab lapang (LL) dan kering udara (KU). Kedua perlakuan tersebut dikenakan peda setiap contoh, sehingga pada setiap jenis tanah diperoleh $2 \times 25$ sub contoh yang setara dengan jumlah satuan percobaan. Sifat-sifat yang berkaitan dengan kesuburan dan klasifikasi tanah ditetapkan dari kedua contoh LL dan KU tersebut (Tabel 1).

Pengaruh perlakuan diuji menurut metode Match Pair Comparison (Johnson dan Bhattacharya, 1985). Hipotesis yang diuji adalah $H 0: \delta=0$ dan $H 1: \delta \neq 0$, dimana $\delta$ adalah perbedaan nilai sifat dari contoh LL dan $\mathrm{KU}$. Untuk populasi contoh, $\delta=d$. Selanjutnya dilakukan perhitungan :

$$
\bar{d}=\frac{\sum d i}{n}
$$

dimana:

$\mathrm{di}=$ perbedaan nilai sifat dari contoh $k e \mathrm{i}$,

$n=$ jumlah contoh dasar $(n=25)$.

Pengujian pengaruh perlakuan didasarkan pada uji-t sebagai berikut:

$$
\frac{\bar{d}}{s d / \sqrt{n}} \approx t
$$

Pengujian pengaruh pengeringan terhadap hasil klasifikasi dilakukan secara kualitatif, yaitu dengan membandingkan hasil klasifikasi dari contoh LL dan KU.

\section{HASIL DAN PEMBAHASAN \\ Pengaruh Pengeringan Contoh terhadap Sifat Tanah}

Data rata-rata sifat fisik dan kimia tanah, ratarata selisih nilai sifat tanah LL dan KU (d) serta hasil pengujian statistiknya disajikan pada Tabel 2. Meskipun pengeringan berpenganuh tidak nyata $(p>0.05)$ terhadap kadar debu dan liat tetapi cenderung meningkatkan nilai kadar debu dan menurunkan nilai kadar liat, sedangkan kadar pasir dipengaruhi secara sangat nyata $(p<0.01)$. Dalam hal ini, pengeringan meningkatkan nilai kadar pasir (Gambar 1).

Fenomena tersebut menunjukan bahwa pada tanah vertik, liat penyusun bahan tanah bersifat irreversible terhadap pengeringan, walaupun intensitasnya rendah. Pengeringan menyebabkan liat beragregasi membentuk butiran yang lebih besar dan tidak sempat saling terlepas kembali secara sempuma pada saat penetapan tekstur. Ini menyebabkan kadar liat menurun secara semu, karena terjadi penambahan pasir dan debu sebagai pseudosand dan pseudositt. 
Tabel 1. Sifat-sifat Fisik dan Kimia Tanah yang Dianalisis dan Metode Analisisnya

\begin{tabular}{|c|c|c|}
\hline No & Sifat Tanah & Metode Analisis \\
\hline 1. & $\mathrm{pH} \mathrm{H} \mathrm{O}_{2}$ dan $\mathrm{pH} \mathrm{KCl}$ & Elektroda Gelas \\
\hline 2. & C-Organik & Modifikasi Walkley dan Black \\
\hline 3. & KTK tanah & $\mathrm{NH}_{4} \mathrm{OAC}$ (Peech et al., 1947 dalam SCS, 1972) \\
\hline 4. & 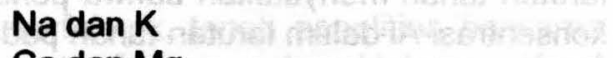 & $\mathrm{NH}_{4} \mathrm{OAc}$, Flame Photometer \\
\hline 5. & Ca dan $\mathrm{Mg}$ & $\begin{array}{l}\mathrm{NH}_{4} \mathrm{OAC}, \text { AAS } \\
\text { KCI }\end{array}$ \\
\hline 6. & $\begin{array}{l}\text { Al dan } \mathrm{H} \\
\text { Kemasaman Dapat Ditukar (EA) }\end{array}$ & $\begin{array}{l}\mathrm{KCl} 1 \mathrm{~N} \text {, Titrasi (SCS, 1972) } \\
\mathrm{BaCl}_{2} \text { metanolamin pH 8.2, Titrasi (SCS, 1972) }\end{array}$ \\
\hline 8. & Tekstur & Pipet (SCS, 1984) \\
\hline 9. & Mineral Liat & X-Ray Difractometer \\
\hline 10. & Mineral Fraksi Pasir & Line Counting \\
\hline & COLE & \\
\hline
\end{tabular}

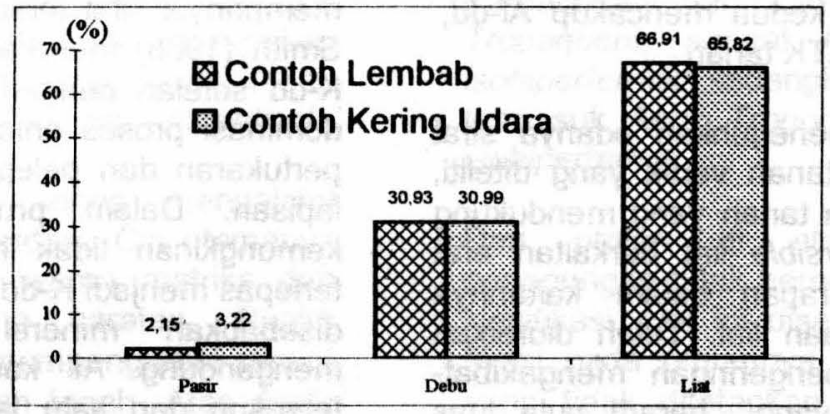

Gambar 1. Histogram Nilai Rata-rata Kadar Pasir, Debu dan Liat dari Contoh LL dan KU

Tabel 2. Rataan Nilai dan Selisih Nilai (d) Sifat Fisik dan Kimia Tanah dari Contoh LL dan KU serta Hasil Uji Statistiknya

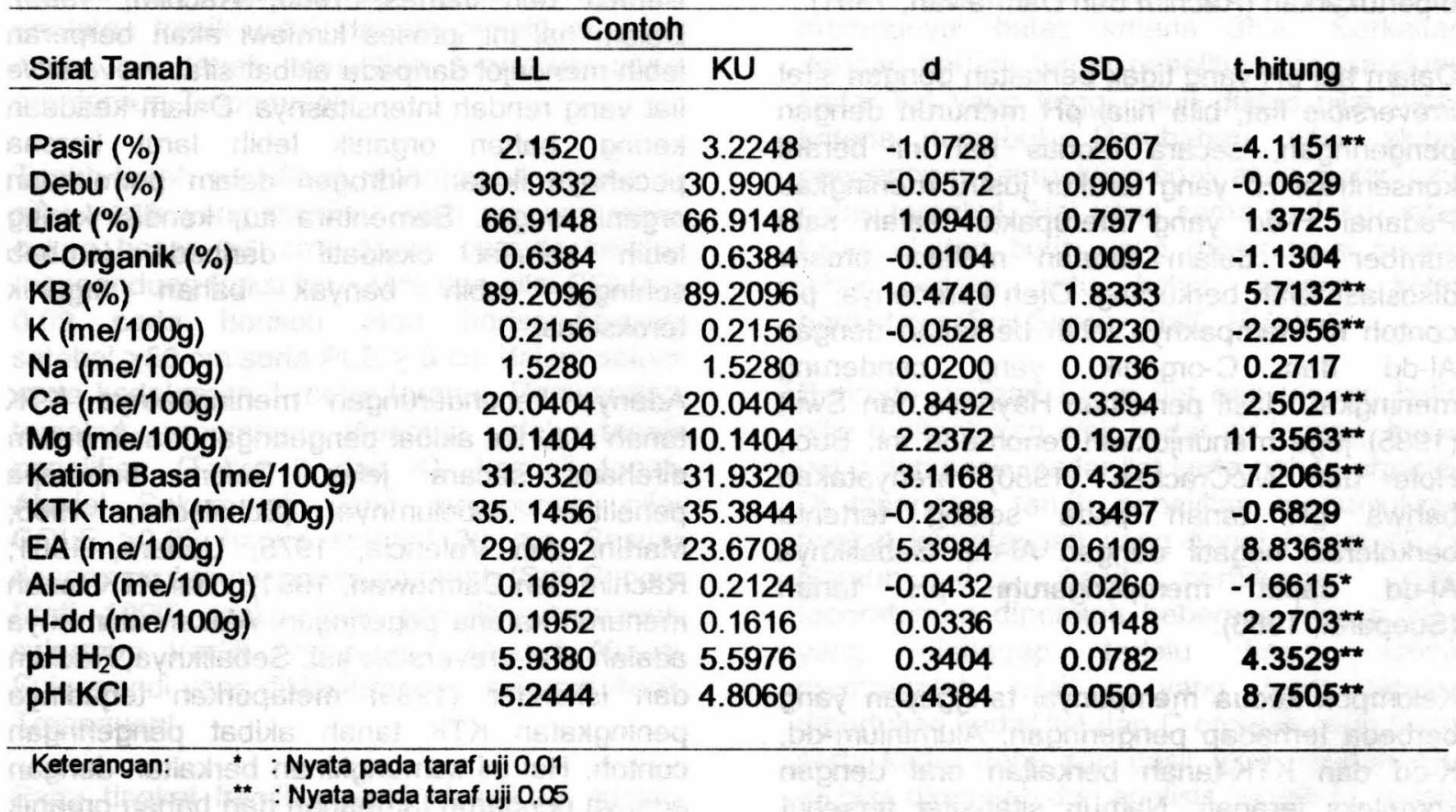


Pengeringan berpengaruh nyata pada taraf $\alpha$ 0.05 (Tabel 2) terhadap sebagian besar sifatsifat kimia tanah yang diuji. Sifat-sifat tersebut meliputi $\mathrm{pH} \mathrm{H}_{2} \mathrm{O}$, pH KCl, $\mathrm{H}$-dd, Al-dd, EA, Kdd, Ca-dd, Mg-dd, jumlah basa dan KB. Sifat yang tidak dipengaruhi secara nyata adalah KTK tanah, C-organik dan Na-dd.

Berdasarkan pola perbedaan nilai, sifat-sifat kimia tanah yang diuji dapat dikelompokkan kedalam 2 kelompok, yaitu kelompok yang mempunyai nilai rata-rata contoh LL lebih besar dari contoh $\mathrm{KU}$ dan kelompok dengan nilai ratarata contoh LL lebih kecil dari contoh KU. Kelompok pertama tendiri dari pH, H-dd, EA, $\mathrm{Na}$-dd, Ca-dd, Mg-dd, jumlah basa dan KB, sedangkan kelompok kedua mencakup Al-dd, K-dd, C-organik, dan KTK tanah.

Kelompok pertama meneguhkan adanya sifat irreversible liat pada tanah vertik yang diteliti, kecuali $\mathrm{pH}$. Sifat kimia tanah yang mendukung eksistensi sifat irreversible liat berkaitan erat dengan kompleks jerapan dalam kaitannya dengan luas permukaan liat. Telah diuraikan sebelumnya bahwa .pengeringan mengakibatkan nilai kadar liat, yang berarti pula luas permukaan atau kompleks jerapan aktual, cenderung menurun (Martini dan Palencia, 1975). Dengan demikian, jumlah kation-kation yang dapat dipertukarkan juga menurun karena sebagian terhalangi oleh agregasi dan tidak bisa dipertukarkan (Rachim dan Damawan, 1991).

Dalam hal pH yang tidak berkaitan dengan sifat irreversible liat, bila nilai $\mathrm{pH}$ menurun dengan pengeringan, secara teoritis hal ini berarti konsentrasi $\mathrm{H}^{+}$yang terukur justru meningkat. Padahal H-dd yang merupakan salah satu sumber $\mathrm{H}^{+}$dalam larutan melalui proses disosiasi telah berkurang. Oleh karenanya, pH contoh KU tampaknya lebih berkaitan dengan Al-dd dan C-organik, yang cenderung meningkat. Hasil penelitian Hayness dan Swift (1985) juga menunjukkan fenomena ini. Buol, Hole dan McCracken (1980) menyatakan bahwa pH tanah pada selang tertentu berkolerasi negatif dengan Al-dd. Sebaliknya Al-dd dapat mempengaruhi pH tanah (Soepardi, 1983).

Kelompok kedua mempunyai tanggapan yang berbeda terhadap pengeringan. Aluminium-dd, K-dd dan KTK-tanah berkaitan erat dengan kompleks jerapan. Namun sifat-sifat tersebut tidak menyebabkan penurunan nilai bila contoh dikering-udarakan. Beberapa peneliti seperti
Bartlett dan James (1980); Hayness dan Swift (1985); Rachim dan Darmawan (1991) melaporkan hal yang sama. Menzies, Bell, dan Edwards (1991) yang meneliti komposisi larutan tanah menyatakan bahwa penambahan konsentrasi Al dalam lantan tanah pada contoh yang dikering-udarakan dan . dibasahkan kembali díbandingkan contoh lembab lapang, adalah akibat dari peningkatan konsentrasi Al yang dikompleks secara organik.

Terdapat kesamaan perilaku antara Al-dd dengan K-dd. Menurut Leubs et al. (1956), tanah yang mengandung liat tipe 2:1 tinggi cenderung melepaskan K-non-dd ke K-dd dalam keadaan kering udara. Tanah penelitian mempunyai sifat tersebut (Tabel 5). Scott dan Smith (1968) menerangkan bahwa perubahan K-dd setelah pengeringan tergantung kepada dominasi proses antara fiksasi $K$ pada lokasi pertukaran dan pelepasan $K$ akibat hancuran lapisan. Dalam proses hancuran lapisan, kemungkinan tidak hanya $K$ terfiksasi yang terlepas menjadi $K$-dd, tetapi juga $\mathrm{Al}-\mathrm{dd}$. Hal ini disebabkan mineral liat tipe 2:1 juga mengandung Al karena struktur kristalnya tersusun dari satu lapisan Al-oktahedral dan dua lapisan Si-tetrahedral (Borchardt, 1989).

Kecenderungan peningkatan C-organik akibat pengeringan telah dilaporkan pula oleh peneliti sebelumnya (Raveh dan Avnimelech, 1978; Bartlett dan James, 1980; Rachim, 1989). Dalam hal ini, proses kimiawi akan berperan lebih menonjol daripada akibat sifat irreversible liat yang rendah intensitasnya. Dalam keadaan kering, bahan organik lebih lant karena pecahnya ikatan hidrogen dalam permukaan organik segar. Sementara itu, kondisi kering lebih bersifat oksidatif daripada lembab sehingga lebih banyak bahan organik teroksidasi.

Adanya kecenderungan meningkatnya KTK tanah atau liat akibat pengeringan masih belum difahami secara jelas. Dalam beberapa penelitian sebelumnya (Schalscha, 1965; Martini dan Valencia, 1975; Uehara, 1981; Rachim dan Darmawan, 1991), nilai KTK tanah menurun karena pegeringan. Alasan utamanya adalah sifat irreversible liat. Sebaliknya, Rachim dan Iskandar (1989) melaporkan terjadinya peningkatan KTK tanah akibat pengeringan contoh. Hal ini kemungkinan berkaitan dengan adanya penganuh tambahan dari bahan organik sehingga KTK menjadi lebih tinggi dalam keadaan kering udara. 


\section{Pengaruh Pengeringan terhadap Klasifikasi Tanah}

Data yang diperlukan dalam pengklasifikasian tanah penelitian disajikan pada Tabel 3 dan 4.

Secara morfologik, tanah penelitian berwama kelabu atau/hingga kecoklatan. Karat terbentuk hampir di seluruh profil. Struktur tanah masif hingga gumpal, tanpa perkembangan hingga lemah. Bahan tanah sering mengalami proses reduksi dan oksidasi, walaupun reduksi lebih dominan. Namun demikian, bahan tanah sudah matang dengan nilai $\mathbf{n}<0.7$ pada sebagian besar profil. Hal tersebut menunjukkan bahwa tanah sudah mengalami perkembangan walaupun lemah. Horison bawah penciri dalam hal ini termasuk kambik, sedangkan horison atas merupakan epipedon okrik. Dengan penciri ini, tanah penelitian tergolong ke dalam order Inceptisol.

Tanah-tanah penelitian sering mengalami keadaan reduksi dan oksidasi. Ciri utamanya adalah kroma $\leq 2$ pada warna matriks dan kroma >2 pada warna karatan. Regim kelembaban akuik telah mempengaruhi secara tegas arah perkembangan tanah. Atas dasar sifat tersebut, tanah penelitian tergolong suborder Aquept. Dengan adanya karat-karat berkroma tinggi, sifat akuik tidak tipikal, tetapi juga bersifat aerik. Penciri kJasifikasi kategori berikutnya adalah keadaan iklim, yang dicirikan oleh regim temperatur isohiperthermik dan/atau tropik untuk daerah penelitian. Atas dasar ini, tanah penelitian termasuk pada greatgroup Tropaquept.

Tanah-tanah penelitian umumnya mempunyai sifat vertik yang dicirikan oleh rekahan yang cukup besar $(\geq 1 \mathrm{~cm})$ dalam periode kering, mengandung fraksi liat $\geq 35 \%$ dan nilai COLE $\geq$ 0.09 pada horison atau horison-horison setebal $>50 \mathrm{~cm}$ serta PLE $>6 \mathrm{~cm}$ dalam solum pada kedalaman 1 meter teratas. Persyaratan tersebut umumnya dipenuhi oleh tanah penelitian (Tabel 3 dan 4), kecuali tanah Aluvial Sukamandi yang mempunyai nilai COLE $\geq 0.09$ hanya setebal $30 \mathrm{~cm}$. Sesuai dengan urutan pengkelasan tanah (Soil Survey Staff, 1990), maka tanah penelitian termasuk subgroup Vertik Tropaquept, kecuali Aluvial Sukamandi yang diklasifikasikan sebagai Aerik Tropoquept.

Pada tingkat famili, penciri kasifikasi adalah kelas ukuran butir, kelas mineralogi dan regim temperatur. Komponen pencin tersebut pada masing-masing tanah penelitian tertera pada Tabel 5.

Analisis mineral liat dilakukan terhadap horison penciri dengan metode difraksi sinar-X. Hasil analisis mineral liat utama disajikan pada Tabel 6. Sesuai dengan kriteria kelas mineralogi menurut Soil Survey Staff (1990), tanah Aluvial Sukamandi mempunyai kelas mineralogi kaolinitik dan kelompok tanah Aluvial lainnya mempunyai kelas mineralogi montmorilonitik.

Data pada Tabel 5 menunjukkan bahwa penciri klasifikasi pada contoh LL maupun KU adalah sama, sehingga nama tanahnyapun juga sama. Dalam hal ini, Aluvial Karawang, Pamanukan dan Cirebon termasuk Vertik Tropaquept, sangat halus, montmorilonitik, isohipertermik; sedangkan Aluvial Sukamandi termasuk Aeric Tropoquept, halus, kaolinitik, isohipertermik.

Dari uraian di atas diketahui bahwa pengeringan tidak berpengaruh terhadap hasil klasifikasi. Hal ini disebabkan penentu klasifikasi pada umumnya adalah sifat morfologi yang tidak ditetapkan di laboratorium. Sifat penciri yang berkaitan dengan pengeringan hanyalah kadar liat atau tekstur, kelas ukuran butir dan nilai $\mathbf{n}$. Pada tanah yang masih muda seperti tanah penelitian, kadar liat kurang berperan menentukan jenis horison penciri. Namun ia menentukan sifat vertik yang mempunyai batas kriteria $35 \%$. Berkaitan dengan hal ini, tanah penelitian mengandung kadar liat yang tinggi, jauh diatas nilai batas kriteria tersebut. Perubahan nilai akibat pengeringan tampaknya tidak akan melampaui batas tersebut. Hal yang sama berlaku untuk kelas ukuran butir, yang mempunyai selang lebar antara satu kelas dengan kelas berikutnya (Soil Survey Staff, 1975).

Berbeda dengan kadar liat dan ukuran butir, nilai $\mathbf{n}$ ditentukan oleh kadar air lapang, kadar debu dan pasir, kadar liat serta bahan organik. Di lapangan, tanah penelitian menunjukkan tingkat kematangan yang tinggi (nilain <0.7). Namun dari hasil perhitungan data laboratorium diperoleh beberapa nilai $n>0.7$ yang dianggap terlalu tinggi. Untuk memperoleh nilai $\mathbf{n}$ yang lebih rendah diperlukan kadar liat dan C-organik yang tinggi serta kadar debu dan pasir lebih rendah. Hal ini bisa diperoleh dari analisis contoh $L L$ (pasir, debu, liat) dan cntoh KU (C-organik). 
Tabel 3. Sifat-sifat Morfologi Penciri Klasifikasi Tanah Penelitian

\begin{tabular}{|c|c|c|c|c|c|c|}
\hline \multirow{2}{*}{$\begin{array}{l}\text { Kedalaman } \\
\text { (cm) }\end{array}$} & \multirow[t]{2}{*}{ Horison } & \multicolumn{2}{|c|}{ Wama } & \multirow{2}{*}{$\begin{array}{c}\text { Perkembangan } \\
\text { Struktur }\end{array}$} & \multirow{2}{*}{$\begin{array}{c}\text { Relohan } \\
\text { (cm) }\end{array}$} & \multirow{2}{*}{$\begin{array}{c}\text { Gejala } \\
\text { Lain }\end{array}$} \\
\hline & & Matriks & Karat & & & \\
\hline $\begin{array}{c}\text { Aluvial Karawang } \\
0-33 \\
33-54 \\
5474 \\
74-126 \\
126-140\end{array}$ & $\begin{array}{l}A p \\
2 A_{2} \\
3 A B_{1} \\
3 A B_{2} \\
3 B C\end{array}$ & $\begin{array}{l}10 \text { YR } 3 / 2-4 / 1 \\
10 \text { YR } 3 / 1-4 / 1 \\
10 \text { YR } 5 / 1-5 / 2 \\
10 \text { YR } 5 / 1-5 / 2 \\
10 \text { YR } 5 / 1-5 / 2\end{array}$ & $\begin{array}{c}7.5 \text { YR 4/3-4/4 } \\
10 \text { YR 3/4-4/4 } \\
10 \text { YR 5/6 } \\
10 \text { YR 5/6 } \\
10 \text { YR 5/6 }\end{array}$ & $\begin{array}{l}0-1 \\
0-1 \\
0-1 \\
0-1 \\
0-1\end{array}$ & $=\begin{array}{c}>1 \\
1 \\
\vdots \\
-\end{array}$ & $\begin{array}{l}- \\
\text { bk } \\
\text { bk } \\
\text { bk }\end{array}$ \\
\hline $\begin{array}{c}\text { A } \\
0-20 \\
20-50 \\
50-92 \\
92-130 \\
130-150\end{array}$ & $\begin{array}{c}A p \\
A_{2} \\
2 B C_{1} \\
3 B C_{2} \\
4 B C_{3}\end{array}$ & $\begin{array}{l}10 \mathrm{YR} 5 / 1-5 / 2 \\
10 \mathrm{YR} 4 / 1-5 / 1 \\
10 \mathrm{YR} 5 / 3 \\
10 \mathrm{YR} 5 / 1-5 / 2 \\
10 \mathrm{YR} 5 / 1-5 / 2\end{array}$ & $\begin{array}{c}10 \text { YR } 4 / 6 \\
7.5 \text { YR } 5 / 6 \\
5 \text { YR } 4 / 6 \\
5 \text { YR } 4 / 6 \\
5 \text { YR } 4 / 6\end{array}$ & $\begin{array}{l}0-1 \\
0-1 \\
0-1 \\
0-1 \\
0\end{array}$ & $\begin{array}{c}>1 \\
1 \\
- \\
- \\
-\end{array}$ & $\begin{array}{l}- \\
\text { bk } \\
\text { bk } \\
\text { bk }\end{array}$ \\
\hline $\begin{array}{c}\text { Aluvial Pamanukan } \\
0-28 \\
28-48 \\
48-68 \\
68-97 \\
97-140 \\
\text { Aluvian }\end{array}$ & $\begin{array}{l}A p \\
2 A_{2} \\
2 A B_{1} \\
3 A B_{2} \\
4 B C_{3}\end{array}$ & $\begin{array}{c}10 Y R 5 / 2 \\
10 Y R 5 / 1-6 / 2 \\
10 Y R 5 / 1+3 / 4 \\
10 Y R 5 / 4+5 / 1 \\
10 \text { YR } 5 / 1\end{array}$ & $\begin{array}{c}7.5 \text { YR } 534 \\
7.5 \text { YR \% } \\
- \\
7.5 \text { YR \% }\end{array}$ & $\begin{array}{l}0 \\
0-1 \\
0-1 \\
0-1 \\
0\end{array}$ & $\begin{array}{l}>1 \\
- \\
- \\
-\end{array}$ & $\begin{array}{l}\text { - } \\
\text { bk } \\
\text { bk } \\
\text { bk } \\
\text { bk }\end{array}$ \\
\hline $\begin{array}{c}0-20 \\
20-50 \\
50-80 \\
80-130 \\
130-150 \\
\text { Aluvial Cirebon }\end{array}$ & $\begin{array}{l}A p \\
2 A_{2} \\
2 A B_{1} \\
3 B_{2} \\
3 B C\end{array}$ & $\begin{array}{c}10 \text { YR } 5 / 1 \\
10 \text { YR } 5 / 1-5 / 2 \\
10 \text { YR 3/1 } \\
10 \text { YR } 3 / 1-4 / 1 \\
10 \text { YR } 5 / 1\end{array}$ & $\begin{array}{c}7.5 \text { YR } 6 / 4 \\
5 \text { YR } 3 / 4 \\
10 \text { YR 5/4 } \\
7.5 \text { YR } 3 / 2 \\
7.5 \text { YR } 4 / 6\end{array}$ & $\begin{array}{c}0 \\
0-1 \\
0-1 \\
0 \\
0\end{array}$ & $\begin{array}{l}>1 \\
1 \\
- \\
- \\
-\end{array}$ & $\begin{array}{l}- \\
\text { bk } \\
\text { bk } \\
\text { bk }\end{array}$ \\
\hline $\begin{array}{c}\text { Aluvial Ciredon } \\
0-24 \\
24-45 \\
45-80 \\
80-105 \\
105-150 \\
\end{array}$ & $\begin{array}{l}\mathrm{Ap} \\
2 \mathrm{~A}_{2} \\
3 \mathrm{AB} \\
3 \mathrm{CB}_{1} \\
4 \mathrm{CB}_{2}\end{array}$ & $\begin{array}{l}10 \text { YR } 4 / 1-5 / 1 \\
10 \text { YR } 4 / 1-5 / 1 \\
10 Y R 3 / 1 \\
10 \text { YR } 3 / 1-4 / 1 \\
10 Y R \quad 6 / 1-6 / 2 \\
\end{array}$ & $\begin{array}{c}7.5 \text { YR 5/6 } \\
10 \text { YR 4/4 } \\
- \\
- \\
10 Y R \text { 4/6 }\end{array}$ & $\begin{array}{c}0 \\
0-1 \\
0-1 \\
0 \\
0\end{array}$ & $\begin{array}{l}>1 \\
1 \\
1 \\
- \\
-\end{array}$ & $\begin{array}{l}- \\
\text { bk } \\
\text { bk } \\
-\end{array}$ \\
\hline
\end{tabular}

- : tidak ada atau tidak ditetapkan; bk. bidang kilir

Tabel 4. Sifat-sifat Penciri Klasifikasi Tanah Penelitian (Fisik dan Kimia)

\begin{tabular}{|c|c|c|c|c|c|c|c|c|c|}
\hline \multirow{2}{*}{$\begin{array}{l}\text { Kedalaman } \\
\text { (cm) }\end{array}$} & \multirow[t]{2}{*}{ Horison } & \multicolumn{2}{|c|}{ Liat } & \multirow[t]{2}{*}{ COLE } & \multirow[t]{2}{*}{ PLE } & \multicolumn{2}{|c|}{ Nilaton } & \multicolumn{2}{|c|}{ Ukuran Butir } \\
\hline & & $\mathrm{LL}$ & KU & & & $\overline{L L}$ & KU & $\mathrm{LL}$ & KU \\
\hline \multicolumn{10}{|c|}{ Aluvial Karawang } \\
\hline 0.33 & Ap & 64.60 & 63.95 & 0.118 & 3.894 & 0.4 & 0.4 & vec & vec \\
\hline $33-54$ & $2 A_{2}$ & 64.80 & 61.57 & 0.117 & 2.475 & 0.5 & 0.5 & vic & ve \\
\hline 5474 & $3 A B_{1}$ & 58.97 & 55.04 & 0.096 & 1.920 & 0.7 & 0.8 & fo & fc \\
\hline 74126 & $3 A B_{2}$ & 68.95 & 67.69 & - & - & 0.7 & 0.7 & vic & vec \\
\hline $126-140$ & $3 B C^{\circ}$ & 71.12 & 72.79 & - & - & 0.8 & 0.8 & vic & vic \\
\hline \multicolumn{10}{|c|}{ Aluvial Sukamandi } \\
\hline $0-20$ & Ap & 47.31 & 50.41 & 0.085 & 1.700 & 0.6 & 0.5 & fc & fe \\
\hline $20-50$ & $A_{2}$ & 42.51 & 49.67 & 0.140 & 4.200 & 0.6 & 0.6 & tc & tc \\
\hline $50-92$ & $2 \mathrm{BC}_{1}$ & $\mathbf{3 7 . 7 6}$ & 38.92 & 0.044 & 1.848 & 0.7 & 0.7 & ic & tc \\
\hline $92-130$ & $3 B C_{2}$ & 58.48 & 62.39 & - & - & 0.5 & 0.5 & te & fe \\
\hline $130-150$ & $4 \mathrm{BC}_{3}$ & 60.86 & 58.03 & - & $\therefore$ & 0.5 & 0.6 & vec & fc \\
\hline \multicolumn{10}{|c|}{ Aluvial Pamanukan } \\
\hline $0-28$ & Ap & $70-79$ & 70.06 & 0.152 & 4.256 & 0.7 & 0.7 & vic & ve \\
\hline $28-48$ & $2 A_{2}$ & 71.34 & 66.64 & 0.172 & 3.440 & 0.7 & 0.7 & vic & ve \\
\hline $48-68$ & $2 A B_{1}$ & 68.26 & 64.59 & 0.179 & 3.580 & 0.6 & 0.6 & vic & vec \\
\hline $68-97$ & $3 \mathrm{BB}_{2}$ & 67.28 & 61.27 & - & - & 0.6 & 0.6 & vic & vic \\
\hline $97-140$ & $4 \mathrm{BC}_{3}$ & 70.87 & 72.02 & - & 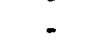 & 0.6 & 0.5 & vic & ve \\
\hline \multicolumn{10}{|c|}{ Aluvial Losarang } \\
\hline $0-20$ & Ap & 75.22 & 73.63 & 0.142 & 2.840 & 0.6 & 0.6 & ve & vic \\
\hline $20-50$ & $2 A_{2}$ & 75.91 & 66.28 & 0.105 & 3.150 & 0.6 & 0.6 & vic & ve \\
\hline $50-80$ & $2 A B_{1}$ & 74.42 & 72.86 & 0.084 & 2.520 & 0.5 & 0.5 & vic & vic \\
\hline $80-130$ & $3 \mathrm{AB}_{2}$ & 62.61 & 61.01 & - & - & 0.6 & 0.6 & vic & vic \\
\hline $130-150$ & $3 B C$ & 82.21 & 79.80 & 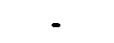 & - & 0.7 & 0.7 & vic & vic \\
\hline \multicolumn{10}{|c|}{ Aluvial Cirebon } \\
\hline $0-24$ & Ap & 74.29 & 73.29 & 0.152 & 0.648 & 0.6 & 0.6 & vic & nec \\
\hline $24-45$ & $2 A_{2}$ & 60.33 & 77.59 & 0.172 & 3.956 & 0.7 & 0.6 & vic & vic \\
\hline 4580 & $3 A B$ & 77.00 & 75.50 & 0.1791 & 6.285 & 0.7 & 0.7 & vec & vic \\
\hline $\begin{array}{l}80-105 \\
105-150\end{array}$ & ${ }_{3 C B_{1}}$ & 81.26 & 74.68 & - & F & 0.9 & 0.9 & vic & vic \\
\hline
\end{tabular}

L: Contoh tandh lembab; KU: Contoh tanah kering udara

-: Tidak ditetapkan; vfc: Berliat sangat halus; fc: Berliat halus 
Tabel 5. Komponen Penciri Klasifikasi Kategori Famili Tanah yang Diteliti

\begin{tabular}{|c|c|c|c|c|c|c|}
\hline \multirow[t]{2}{*}{ Tanah } & \multicolumn{2}{|c|}{ Liat *) } & \multicolumn{2}{|c|}{ Kelas ukuran butir } & \multirow{2}{*}{$\begin{array}{c}\text { Kelas } \\
\text { Mineralogi }\end{array}$} & \multirow{2}{*}{$\begin{array}{c}\text { Regim } \\
\text { Temperatur }\end{array}$} \\
\hline & LL & $\mathrm{KU}$ & $\mathrm{LL}$ & $\mathrm{KU}$ & & \\
\hline $\begin{array}{l}\text { Aluvial Karawang } \\
\text { Aluvial Sukamandi } \\
\text { Aluvial Pamanukan } \\
\text { Aluvial Losarang } \\
\text { Aluvial Cirebon }\end{array}$ & $\begin{array}{l}64.66 \\
41.61 \\
68.91 \\
71.77 \\
76.13\end{array}$ & $\begin{array}{l}62.20 \\
45.01 \\
64.37 \\
67.51 \\
75.84\end{array}$ & $\begin{array}{l}\text { vfc } \\
\text { fc } \\
\text { vfc } \\
\text { vfc } \\
\text { vfc }\end{array}$ & $\begin{array}{l}\text { Vfc } \\
\text { Fc } \\
\text { Vfo } \\
\text { Vfc } \\
\text { Vic }\end{array}$ & $\begin{array}{l}\text { Mn } \\
\text { Ko } \\
\text { Mn } \\
\text { Mn } \\
\text { Mn }\end{array}$ & $\begin{array}{l}\text { ih } \\
\text { ih } \\
\text { in } \\
\text { in } \\
\text { in }\end{array}$ \\
\hline
\end{tabular}

"): chitung dari bagian kontrol profil; fc: berliat halus; vic: berliat sangat halus;

Ko: kaolinitik; Mn: montmorilonitik; ih: isohipertermik

Tabel 6. Kadar Mineral Fraksi Liat pada Horison Terpilih Tanah-tanah Penelitian

\begin{tabular}{|c|c|c|}
\hline Kelompok Aluvial & Montmorilonit & Kaolinit \\
\hline & & \\
\hline $\begin{array}{l}\text { Karawang } \\
\text { Sukamantri } \\
\text { Pamanukan } \\
\text { Losarang } \\
\text { Cirebon }\end{array}$ & $\begin{array}{l}80 \\
21 \\
61 \\
84 \\
74\end{array}$ & $\begin{array}{l}20 \\
63 \\
30 \\
16 \\
16\end{array}$ \\
\hline
\end{tabular}

\section{KESIMPULAN DAN SARAN}

Berdasarkan penelaahan data percobaan, dapat ditarik beberapa kesimpulan sebagai berikut:

(1) Liat penyusun bahan tanah vertik yang digunakan dalam penelitian ini bersifat irreversible terhadap pengeringan dengan intensitas rendah.

(2) Fraksi liat dan debu tidak dipengaruhi secara nyata, tetapi kadar pasir dipengaruhi secara nyata oleh pengeringan.

(3) Sifat irreversible liat dicerminkan pula oleh sebagian besar sifat kimia tanah yang diukur, kecuali Al-dd, K-dd, KTK, C-organik dan $\mathrm{pH}$.

(4) Pengaruh pengeringan contoh tanah sangat nyata terhadap perubahan $\mathrm{pH}, \mathrm{H}$ dd, Al-dd, EA, Ca-dd, Mg-dd, K-dd, jumlah basa, dan KB, tetapi tidak nyata terhadap Na-dd, KTK tanah dan C-organik.

(5) Pengeringan dapat meningkatkan atau cenderung meningkatkan kadar pasir dan debu, Al-dd, K-dd, KTK tanah dan Corganik; dan menurunkan atau cenderung menurunkan kadar liat, $\mathrm{pH} \mathrm{H}_{2} \mathrm{O}, \mathrm{pH} \mathrm{KCl}, \mathrm{H}-$ dd, EA, Ca-dd, Mg-dd, Na-dd, jumlah basa dan KB.

(6) Perbedaan rata-rata nilai sifat tanah antara contoh $\mathrm{LL}$ dan KU umumnya kecil dipandang dari segi Ilmu Tanah, kecuali untuk $\mathrm{Mg}$ dan $\mathrm{Na}$.
(7) Hasil Klasifikasi tanah penelitian tidak dipenganuhi oleh pengeringan contoh tanah.

(8) Disarankan agar sifat-sifat yang berkaitan dengan kompleks jerapan, termasuk $\mathrm{pH}$, dianalisis dari contoh lembab lapang.

(9) Untuk tujuan klasifikasi, perolehan data tekstur sebaiknye dari contoh lembab lapang.

\section{UCAPAN TERIMA KASIH}

Penulis mengucapkan terimakasih kepada P4M, DPPM, Dit. Jen. Dikti DepDikBud yang telah membiayai penelitian ini. Ucapan terimakasih disampaikan pula kepada Lembaga Penelitian IPB yang telah memberi kepercayaan dan kesempatan kepada penulis untuk melaksanakan penelitian ini.

\section{DAFTAR PUSTAKA}

Bartlett, R. and B. James. 1980. Studying dried, stored soil piffalls. Soil Sci. Am. J. 44:721-724.

Borchardt, G. 1989. Smectites. In Dixon, J.B. and S.B. Weed (eds). Mineralogy in Soil Environments. Second Ed. Soil Sci. Soc. Am., Inc., Madison, pp:675727. 
Buol, S.W., F.D. Hole, and R.J. McCracken. 1980. Soil Genesis and Classification. The State Univ. Press, Ames.

Hayness, R.J. and R.S. Swift. 1985. Effect of air drying on the adsorption and desorption of phosphate and levels of extractable phosphates in a group of acis soils, New Zealand. Geoderma 35:145-157.

Johnson, R. and G. Bhattacharya. 1985. Statistics: Principle and Methods. John Wiley and Sons. New York.

Leubs, R.E., G. Stanford, and A.D, Scott. 1956. Relation of available pottasium to soil moisture. Soil Sci. Soc. Am. Proc. 20:45-50.

Martini, J.A. and J.A. Palencia. 1975. Soil derived from volcanic ash in Central America: I. Andepts. Soil Sci. Soc. Am. Proc. 120: 278-287.

Menzies, N.W., L.C. Bell, and D.G. Edwards. 1991. Effects of incubation time and filtration technique on soil solution composition with particular reference to inorganic and organically complexed Al. Aust. J. Soil Res. 29:223-238.

Rachim, D.A. 1989. Pengaruh kadar air contoh tanah terhadap beberapa sifat fisik dan kimia tanah Andosol. Bul. Penelitian IPB. 7:1-11.

dan Darmawan. 1991. Pengaruh pengeringan contoh tanah terhadap beberapa sifat fisik dan kimia penciri klasifikasi Sistem Taksonomi Tanah pada Latosol dan Podsolik Merah Kuning. Laporan Penelitian, Fakultas Pertanian, IPB, Bogor.

dan Iskandar. 1989. Pengaruh kadar air contoh tanah terhadap beberapa sifat fisik dan kimia Andosol serta tatanamanya menunut Taksonomi Tanah. Laporan Penelitian, Fakultas Pertanian, IPB, Bogor.
Raveh, A. and Y. Avnimelech. 1978. The effect of drying on the coloidal properties and stability of humic compounds. Plant Soil 50:545-552.

Schalscha, E.B. 1965. Effect of drying on volcanic asb soil in Chile. Soil Sci. Soc. Am. Proc. 29:491-492.

Scott, A..D. and A.J. Smith. 1968. Mechanism for soil potassium release by drying. Soil Sci. Soc. Am. Proc. 32:443-444.

Soil Conservation Service. 1972. Soil Survey Laboratory Methods and Procedures for Collecting Soil Samples. USDA, Washington, D.C.

1984. Procedures for Collecting Soil Samples and Methods of Analysis for Soil Survey. USDA, Soil Conserv. Service. Soil Survey Investigations Report No. 1.

Soepardi, G. 1983. Sifat dan Ciri Tanah. Jurusan Tanah, Fakultas Pertanian, IPB, Bogor.

Soil Survey Staff. 1951. Soil Survey Manual. U.S. Dept. Agric. Handb. 18. U.S. Govt. Printing Office, Washington, D.C. 1975. Soil Taxonomy. A Basic System of Soil Classification for Working and Interpreting Soil Survey. Soil Conserv. Service. U.S. Dept. Agric. Handb. 456. U.S. Govt. Printing Office, Washington, D.C. 1990. Keys to Soil Taxonomy. SMSS. Technical Monograph No. 14, Blacksburgh, Virginia.

Uehara, G. and G. Gilman. 1981. The Mineralogy, Chemistry, and Physics of Tropical Soils with Variable Charge Clays. Westview Press, Inc., Colorado.

Walworth, J.L. 1992. Soil drying and rewetting, or freezing and thawing, affects soil solution composition. Soll Sci. Soc. Am. J. 56:433-437. 